663311

r.p. 1289

AEC RESEARCH AND DEVELOPMENT REPORT

\title{
CORROSION OF MAGNESIUM ALLOYS AND CERAMICS
}

\author{
R. S. ONDREJCIN
}
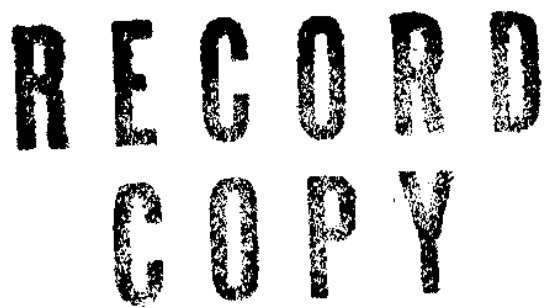

DONOT RELEASE

FROM FILE

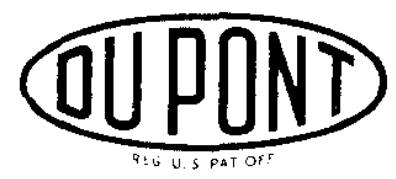

Savannah River Laboratory

Aiken, South Carolina 


\section{NOTICE}

This report was prepared as an account of work sponsored by the United States Govermment. Neither the United States nor the United States Atomic Energy Commission, nor any of their employees, nor any of their contractors, subcontractors. or their employees, makes any warranty. express or implied or assumes any legal liability or responsibility for the accuracy, completeness or usefulness of any information, apparatus, product or process disclosed, or represents that its use would not infringe privately owned rights.

Printed in the United States of America Available from

National Technical Information Service

U. S. Department of Commerce

5285 Port Royal Road

Springfield, Virginia 22151

Price: Printed Copy $\$ 3.00$; Microfiche $\$ 0.95$ 


$$
663<11
$$

Metals, Ceramics, and Materials

(TID-4500, UC-25)

\title{
CORROSION OF \\ MAGNESIUM ALLOYS AND CERAMICS
}

\author{
by \\ R. S. Ondrejcin \\ Approved by \\ R. T. Huntoon, Research Manager \\ Nuclear Materials Division
}

March 1972

E. I. DU PONT DE NEMOURS \& COMPANY

SAVANNAH RIVER LABORATORY

AIKEN, S. C. 29801

CONTRACT AT (07-2)-1 WITH THE

UNITED STATES ATOMIC ENERGY COMMISSION 


\begin{abstract}
The resistance of 42 experimental magnesium alloys to corrosion by hot, refreshed deionized water was determined to select candidate materials for nuclear reactor moderator displacers. The most promising of these alloys were subsequently tested in $80-115^{\circ} \mathrm{C}$ water controlled at $\mathrm{pH} 5$ and flowing $5 \mathrm{ft} / \mathrm{sec}$. Four of these alloys, $\mathrm{Mg}-5 \mathrm{Al}-2 \mathrm{Sn}, \mathrm{Mg}-1 \mathrm{Si}, \mathrm{Mg}-5 \mathrm{Al}-0.5 \mathrm{Ce}$, and $\mathrm{Mg}-3 \mathrm{~A} 1-0.2 \mathrm{Ca}$, are more corrosion resistant than the best commercial alloy tested, AZ31B (3A1-1Zn-0.2Mn); these four alloys also meet the requirement of high scatter and low neutron absorption cross sections. Corrosion rates for all alloys without cladding were too high for reactor use. Limited studies of potential ceramic materials showed that $\mathrm{MgAl}_{2} \mathrm{O}_{4}$ should be suitable, from a corrosion standpoint, as an alternative material if aluminum-clad magnesium alloys were found unsuitable for other reasons.
\end{abstract}




\section{CONTENTS}

Page

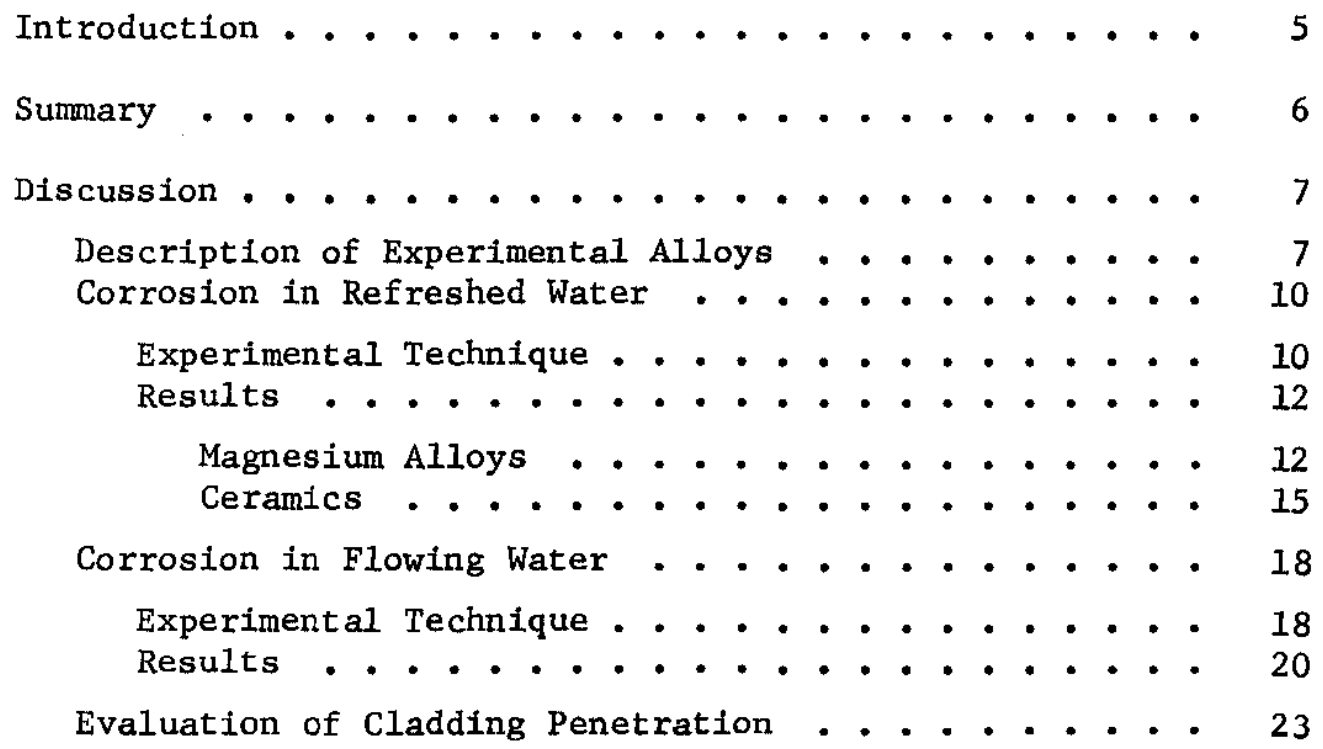

Appendix A - Magnesium Alloys for Corrosion Evaluation . . . . . . . . . . . 27

Appendix B - Ceramics for Corrosion Evaluation . - . . . 28

Acknowledgments . . . . . . . . . . . . . . . 28

References . . . . . . . . . . . . . . . . . 28 


\section{LIST OF FIGURES AND TABLES}

Figure

Page

1 Inhomogeneity of As-Received Magnesium Alloys . . 8

2 Inhomogeneity Reduced by Heat Treatment . . . . . 9

3 Extruded Structure of $\mathrm{Mg}-5 \mathrm{Al}-2 \mathrm{Sn}$ After Billet Heat Treatment . . . . . . . . . . . 10

4 Laboratory Corrosion Test Equipment . . . . . . 11

5 Corrosion Evaluation of Nonhomogenized Alloys . . . 12

6 Corrosion Evaluation of Homogenized Alloys . . . 14

7 Effects of Exposure of Ceramics to $80^{\circ} \mathrm{C}$ Water . . 16

8 Spalling and Cracking of Ceramics in $80^{\circ} \mathrm{C}$ Water. . 17

9 Corrosion Loop Schematic . . . . . . . . 18

10 Loop Sample Holder . . . . . . . . . . 19

11 Types of Corrosion Observed on Magnesium Alloys . . . 21

12 Effect of Some Alloying Elements on Magnesium Corrosion . . . . . . . . . . . . . 23

13 Attack of Aluminum-Clad Magnesium in "Pinhole" Through Cladding . . . . . . . . . . 26

Table

I Corrosion Rates Before and After Alloy Homogenization . . . . . . . . . . . . 13

II Effect of Iron on Magnesium Corrosion in Low Conductivity Water . . . . . . . . . . . . 13

III Corrosion Rates of Selected Magnesium Alloys Refreshed $80^{\circ} \mathrm{C}$, Deionized Water. . . . . . . 15

IV Typical Loop Corrosion Conditions . . . . . . . . . . 19

V Magnesium Alloy Corrosion Rates at $115^{\circ} \mathrm{C}$. . . . 20

VI Temperature Effect on Magnesium Alloy Corrosion in Flowing Water . . . . . . . . . 22

VII Alloying Elements in AZ31B and Corrosion Film . • . . 24

VIII Effect of Increasing Cathodic Area on Magnesium Corrosion . . . . . . . . . . . 25 


\section{INTRODUCTION}

The resistance of magnesium alloys to corrosion in flowing water was evaluated because of their potential for use as a moderator displacer if a Savannah River reactor were converted to resonance operation. This conversion was considered as a means to adjust the neutron spectrum to favor production of certain isotopes such as ${ }^{252} \mathrm{Cf}$.

Excessive corrosion of the moderator displacers would greatly reduce the reliability and control of a resonance reactor. Although magnesium alloys are known to corrode rapidly in certain aqueous environments, ${ }^{1}$ spent, magnesium-alloy-clad fuel elements have been successfully stored in water by controlling the $\mathrm{pH}$ at $12 .^{2}$ Control of $\mathrm{pH}$ at this high a level is not practical in Savannah River reactors because of extensive use of aluminum, the ion exchange system in use, and the potential for caustic stress cracking of sensitized stainless steel welds in the reactor tanks. A more practical method of corrosion control was the use of aluminum-clad magnesium alloys with an overall displacer composition of $90 \mathrm{wt} \% \mathrm{Mg}-10 \mathrm{wt} \% \mathrm{Al}$ (including cladding). However, because of the potential for cladding defects allowing penetration by the moderator, a corrosion-resistant magnesium alloy was desired.

This report describes the results of an evaluation of corrosion resistance of forty-two experimental alloys. These alloys were designed to meet the special requirements of a moderator displacer, low absorption and high scatter cross sections for neutrons and low corrosion rates. Limited corrosion evaluation of several potential ceramic displacers is also included. The mechanical properties and irradiation test results for these same alloys will be reported in another document. 


\section{SUMMARY}

Four experimental alloys, $\mathrm{Mg}-5 \mathrm{Al}-2 \mathrm{Sn}, \mathrm{Mg}-1 \mathrm{Si}, \mathrm{Mg}-5 \mathrm{Al}-0.5 \mathrm{Ce}$, and $\mathrm{Mg}-3 \mathrm{Al}-0.2 \mathrm{Ca}$, have good corrosion resistance to hot flowing water and, when clad with aluminum, might be used as moderator displacer materials to convert a Savannah River heavy water reactor from thermal to resonance operation. These experimental alloys are more corrosion resistant than the best commercial alloy tested, AZ31B (Mg-3A1-1Zn-0.2Mn), and also have the low neutron absorption and high scattering cross sections required for a moderator displacer.

Initial screening of candidate displacer materials was in refreshed deionized water at $80^{\circ} \mathrm{C}$ with zero flow velocity past the test specimens; the more resistant of the 45 magnesium alloys evaluated, corroded at about $12 \mathrm{mg} /\left(\mathrm{dm}^{2}-\right.$ day $)$ at a $\mathrm{pH}$ of $8-9$. Fifteen alloys were selected from these tests and evaluated in a corrosion loop where a side stream of water was continuously deionized, and the loop water was maintained at $\mathrm{pH} 5.0 \pm 0.2$; the temperature was controlled at 80,100 , or $115 \pm 2^{\circ} \mathrm{C}$ and the flow at $5 \mathrm{ft} / \mathrm{sec}$. The corrosion rates of the more-resistant samples rose from about $500 \mathrm{mg} /\left(\mathrm{dm}^{2}\right.$-day) ( $1.1 \mathrm{mils} /$ day penetration) at $80^{\circ} \mathrm{C}$ to about $700 \mathrm{mg} /\left(\mathrm{dm}^{2}\right.$-day) ( $1.6 \mathrm{mils} /$ day penetration) at $115^{\circ} \mathrm{C}$. Pure magnesium $(99.96 \%)$ corroded at about $1900 \mathrm{mg} /$ ( $\mathrm{dm}^{2}$-day) ( $\left.4.3 \mathrm{mils} / \mathrm{day}\right)$ at $115^{\circ} \mathrm{C}$. The lower corrosion rates observed in the experimental alloys are due to the formation of a corrosion film that is typically depleted in magnesium and enriched in the alloying elements.

Galvanically accelerated corrosion of magnesium because of contact with aluminum was not observed in low conductivity water. The corrosion rate of aluminum-clad AZ31B in a 1/16-inch-diameter "pinhole" was about the same as for an unclad AZ31B specimen under no-flow conditions. The aluminum cladding adjacent to the magnesium in the "pinhole" was attacked slightly by the basic solution formed in the pinhole because of dissolution of corrosion products; however, this effect was minor.

The ceramic $\mathrm{MgAl}_{2} \mathrm{O}_{4}$ is a possible alternative displacer material to the magnesium alloys, based on corrosion tests of several oxides. The $<0.9 \mathrm{mg} /\left(\mathrm{dm}^{2}\right.$-day) attack rate observed in the $80^{\circ} \mathrm{C}$ over-flow system for $95 \%$ dense $\mathrm{MgAl}_{2} \mathrm{O}_{4}$ was the lowest observed for any metal or ceramic evaluated. 


\section{DISCUSSION}

\section{DESCRIPTION OF EXPERIMENTAL ALLOYS}

Magnesium alloys are used satisfactorily in some aqueous environments. Generally, water at a pH of about 12 or with a low conductivity, flow rate, and temperature does not attack magnesium. ${ }^{2}$ Under these conditions, the metal is protected by a hydroxide coating, but this compound has a relatively high solubility in water at elevated temperatures $\left(43 \mu \mathrm{g} / \mathrm{ml}\right.$ at $\left.100^{\circ} \mathrm{C}\right)$. Anything, such as an ion exchange resin, that removes $\mathrm{Mg}^{+2}$ or $\mathrm{OH}^{-}$from a solution will increase the magnesium corrosion rate because the hydroxide will dissolve more rapidly to maintain the $\mathrm{Mg}(\mathrm{OH})_{2} \rightleftarrows \mathrm{Mg}^{+2}+2 \mathrm{OH}^{-}$equilibrium. The hydroxide is not very adherent, and loss of the coating leads to high corrosion rates even at lower temperatures, if the flow rate is high.

Very little is known about the use of alloying additions to reduce magnesium corrosion in hot, flowing, low-conductivity water. The only agreement found in the literature ${ }^{1}$ and among the manufacturers was that aluminum additions were helpful. Argonne National Laboratory recommended $\mathrm{Mg}-(2.5-5.0) \mathrm{Al}-(0.8-1.2)$ $\mathrm{Sn}-(0.5-1.0) \mathrm{Cu}$ for corrosion resistance at $150^{\circ} \mathrm{C}$ in initially pure water. ${ }^{3}$ Because of the lack of information about the effect of alloy additions on corrosion resistance under the desired conditions, 45 different magnesium alloys, including 42 experimental ones, were purchased from the Dow Chemical Company for evaluation. The alloys were ordered in two groups; the second group was selected on the basis of the corrosion and metallographic examination of the first group.

The first group of 30 alloys had a variety of alloying elements. This group included three commercial magnesium alloys, $A Z 31 B(3 \mathrm{Al}-1 \mathrm{Zn}-0.2 \mathrm{Mn}), \mathrm{AZ61}(6 \mathrm{Al}-1 \mathrm{Zn}-0.2 \mathrm{Mn})$, and AZ91 (9A1-1Zn$0.2 \mathrm{Mn}$ ), for comparison with the experimental alloys, although the manganese content of the commercial alloys precluded satisfactory neutron properties. Four $\mathrm{Mg}-\mathrm{Fe}$ alloys ranging from 0.001 to 0.1 wt \% were also ordered to evaluate the effect of iron on corrosion of magnesium in low conductivity water. Three $\mathrm{Mg}-\mathrm{Al}$ alloys with an aluminum content ( $>5 \%)$ too high for use in an aluminum-clad displacer were also included to evaluate the effect of this element over a wide alloying range. 
Metallographic examination of the fixst group of alloys showed many of them to be inhomogeneous (Figure 1). Several alloys were given homogenization treatments recommended by the Dow Chemical Company. At the end of recomended homogentation periods, all alloys showed a significant grain growth $(5-10 \mathrm{X})$, and although alloying elements were more homogeneous, they were still concentrated in grain boundartes (Figure 2).

$\operatorname{Mg}-3 A 1-12 n-0.2 M n(A Z 31 B)$

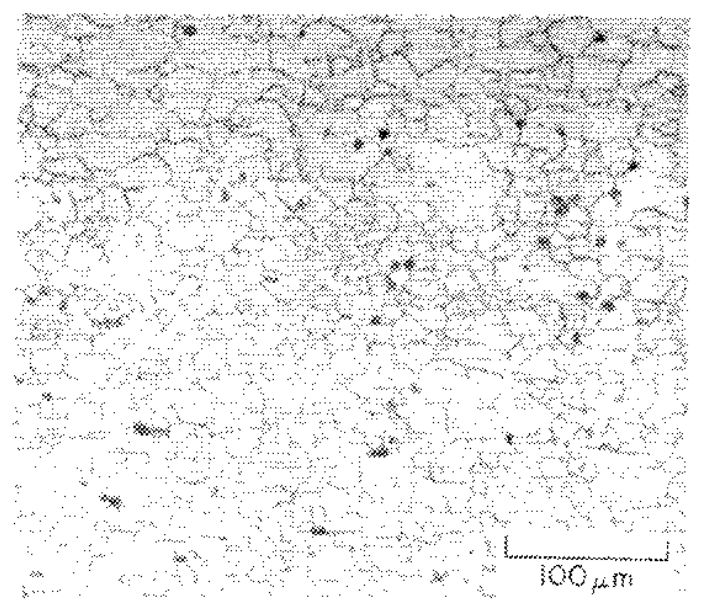

$M g-5 A 1-25 n$

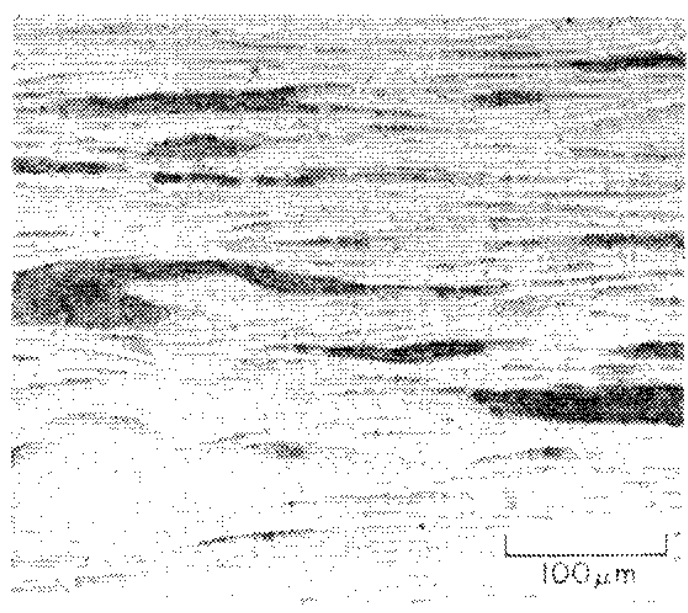

$M g-5 A 1-2 P b-0.05 B e$



$\operatorname{Mg}-6 \mathrm{Zn} n-1 \mathrm{Zn}$

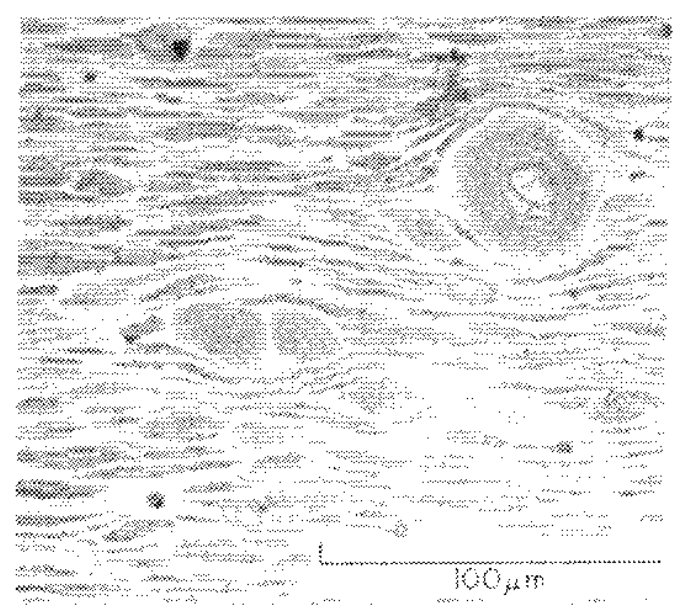

FIG. I Inhomogeneity of As-Received Magnesium Alloys 


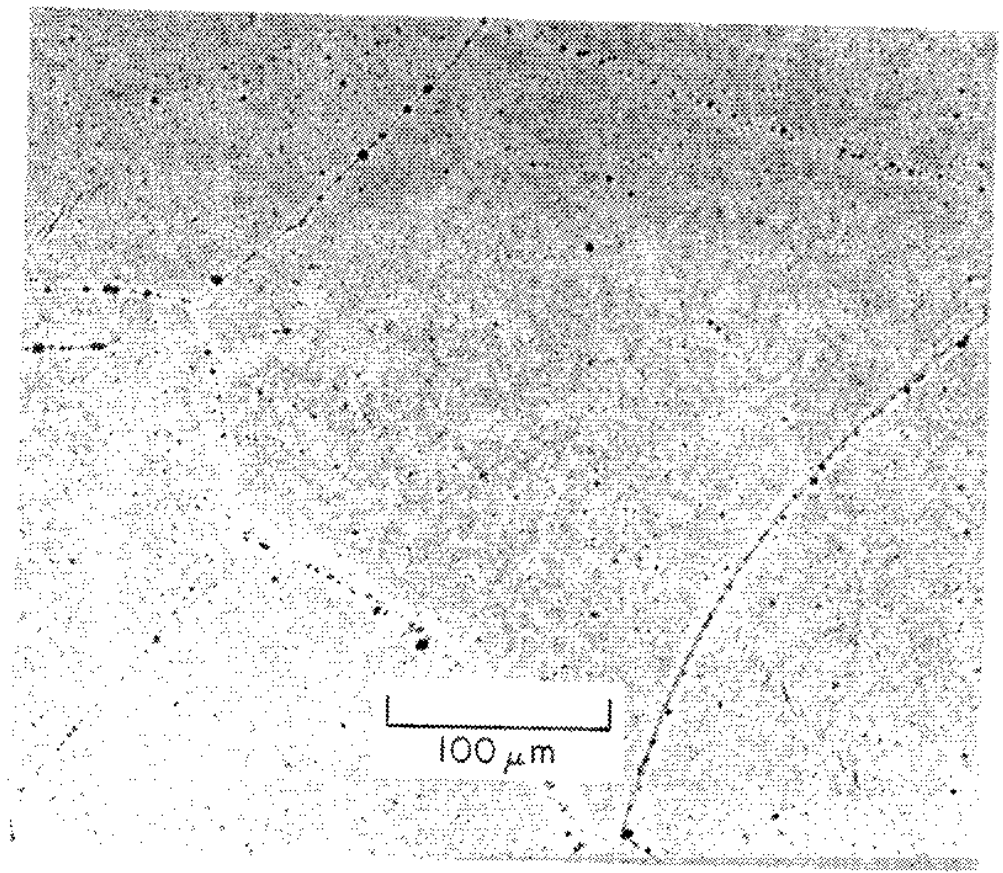

FIG. 2 Inhomogeneity Reduced by heat Treatment

A second series of 15 new alloys were ordered and examined metallographically. the alloying elements $\mathrm{Al}, \mathrm{Be}, \mathrm{Ca}, \mathrm{Ce}$, and Sn were added singly or in combination to make up the second group blllets from both groups of alloys were in the first group, some trusion. prothe heat treated before exnerease antrustons ratios as large as 140:1 were used to further Some prectpitation and to break up billet grain boundartes. the wloys were generally tmproved by and gratn boundaries, but extrustons (figure 3). 


\section{Transverse Section}

n80\% of surface

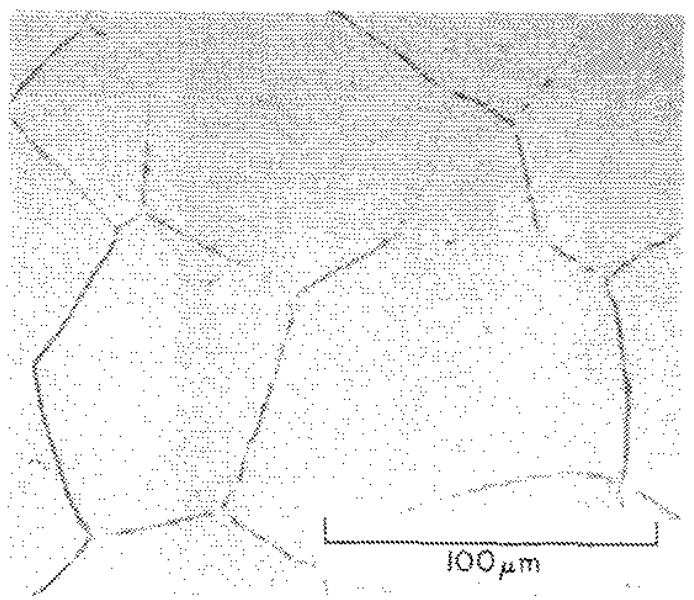

$20 \%$ of surface

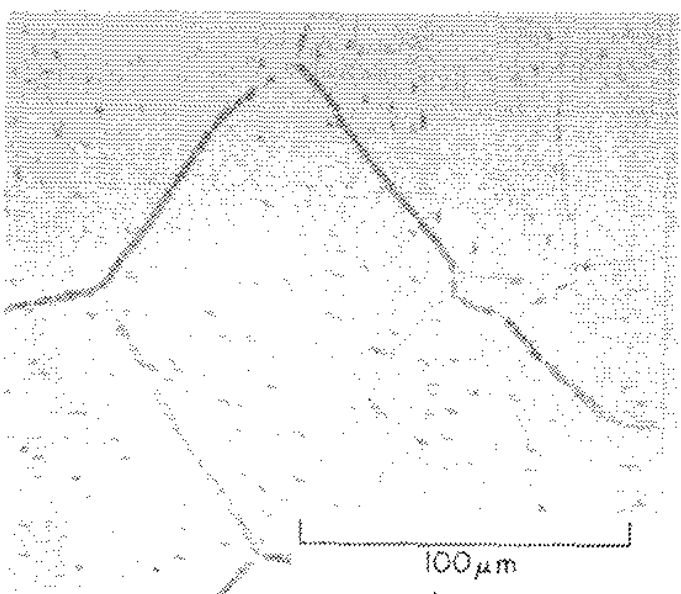

F1G. 3 Extruded Structure of Mg-5Al-2Sn After Billet Heat Treatment

A11 magnesium a1loy composithons oxdered are listed in Appendix A.

\section{CORROS ION IN REFRESHED WATER}

\section{Experimental Technique}

Evaluation was based on the amount of metal oxidized duming trmexston in refreshed, deionlzed water at $80^{\circ} \mathrm{C}$. Water was added to and overflowed from a stalnless steel beaker at a rate of 20 ml. $/ \mathrm{min}$. Spectmens $(50 \times 25 \times 3.2 \mathrm{~mm})$ were insulated from the beaker by nylonm coated holders to prevent galvantc corrosion (figure 4a). The reststivity of water entering the beakex was $>1 \times 10^{\circ}$ ohnm; the overflow had a restgtivity of $1-4 \times 10^{3}$ ohmmen at pu 8m9. This pll represented $0.01-0.1$ ppr of $\mathrm{Mg}$ as $\mathrm{Mg}(\mathrm{OW})_{2} \mathrm{th}$ the water. Temperature of the flowing water was controlled to $80 \$ 1{ }^{\circ} \mathrm{C}$ by 10 wate and bath tempexature (Figure $4 b$ ). This temperature was the highest feasible to matntan a reasonably low CO. concentration (solubility: 0.15 ppm at $80^{\circ} \mathrm{C}$ ) because $\mathrm{CO}_{2}$ accelexates magnesium corrosion, ${ }^{2}, 4$

Candidate alloys were ellminated on the basis of their corrosion rates. The axtent of corrosion was evaluated by determ mindug the weight of metal lost. This change in weight of the specimens was measured after the corrosion film had been stripped in bolling $15 \mathrm{wt} \% \mathrm{CrO}_{3}-1$ wt $\% \mathrm{AgNO}_{3}$. 


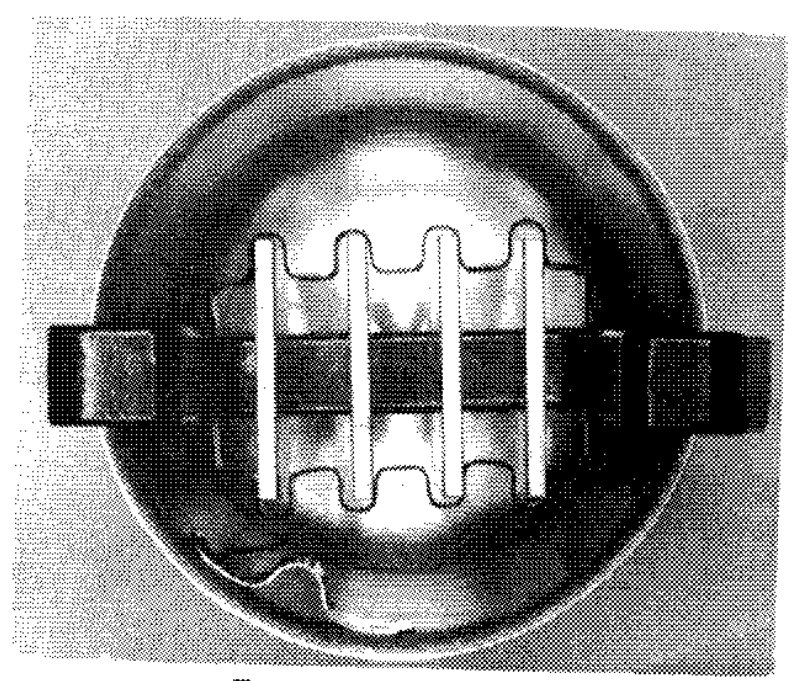

a. Test Alloy in Beaker

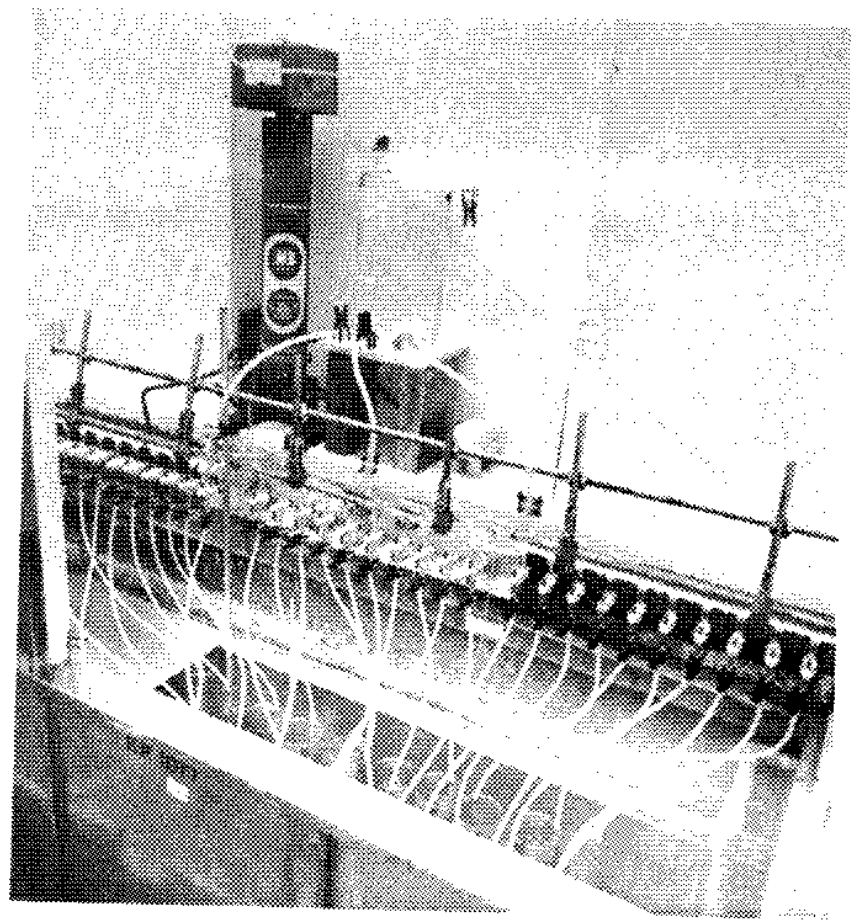

b. Deionized water flows to hold tank, then to manifold and through adjustable stopcocks to individual beakers. Water overflows into recirculating hot water bath that maintains water temperature in the beaker.

FIG. Laboratory Corrosion Test Equipment 


\section{Results}

\section{Magnesium Alloys}

The initial corrosion evaluation of 45 magnesium alloys reduced the number of alloys for further testing to 15.

The corrosion rates of the first group of 30 alloys were measured in duplicate after $1,2,6$, and 9 days exposure in the laboratory equipment. The rates for selected alloys of this group are compared to $99.96 \% \mathrm{Mg}$ in Figure 5 . The most corrosion resistant of the three commercial magnesium alloys was AZ31B ( $3 \mathrm{Al}-1 \mathrm{Zn}-$ $0.2 \mathrm{Mn})$. Al1 alloys corroded at lower rates than $99.96 \% \mathrm{Mg}$ except $\mathrm{Mg}-6 \mathrm{Zn}-0.5 \mathrm{Zr}$.

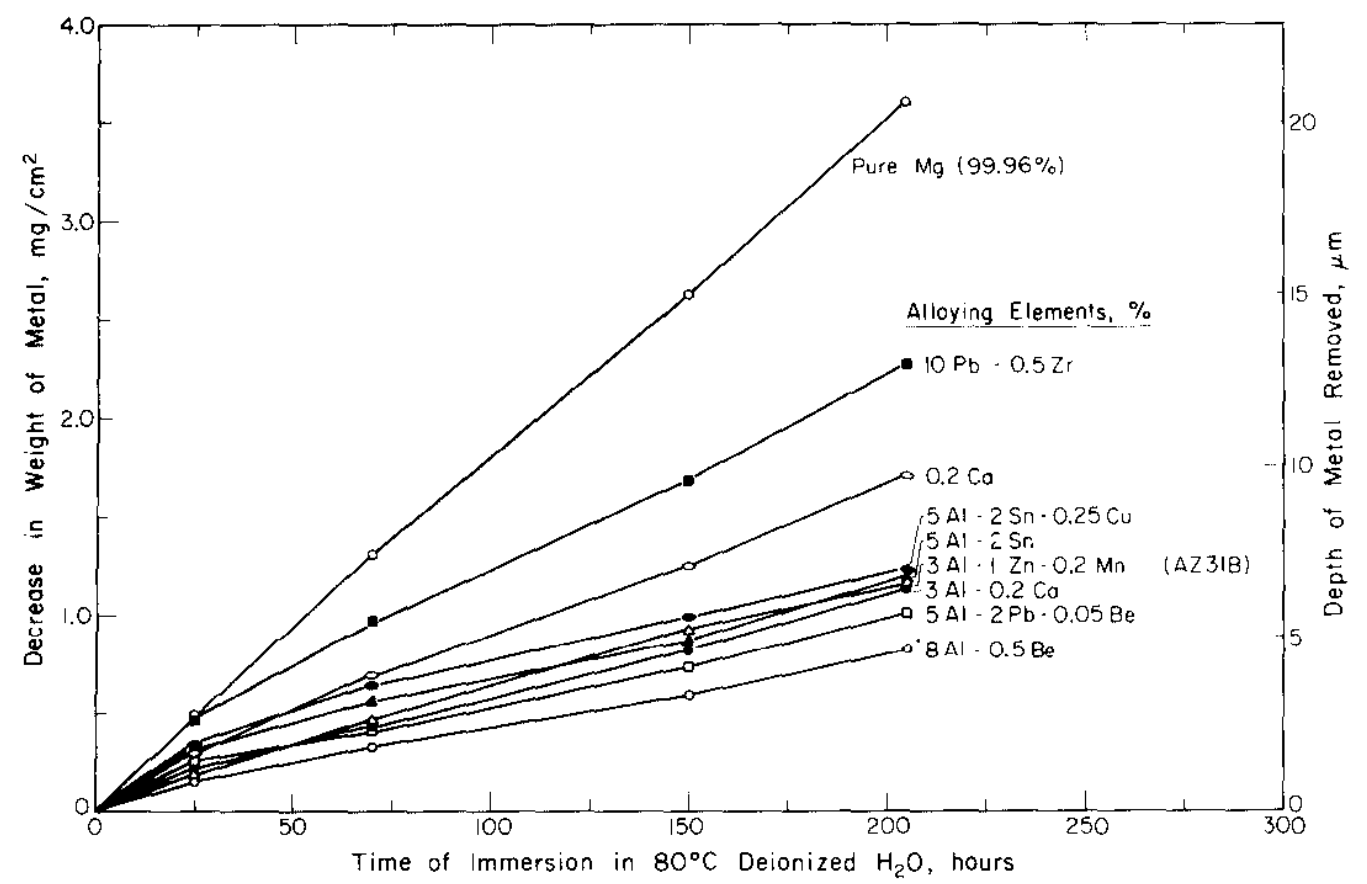

FIG. 5 Corrosion Evaluation of Nonhornogenized Alloys

Homogenization treatments after extrusion did not improve corrosion resistance. Equivalent or poorer corrosion performance was consistently observed after heat treatment. Corrosion rates of several homogenized alloys based on 200 hour tests in $80^{\circ} \mathrm{C}$ refreshed deionized water are tabulated in Table $I$ and compared with as-received controls. Opposite results were expected because inhomogeneity was expected to increase the rate of corrosion, at least locally. An explanation for the increase in corrosion rates may be that heat treatment concentrated the more cathodic alloying elements in the grain boundaries (Figure 3). 


\section{TABLE I}

Corrosion Rates Before and After

Alloy Homogenization

$\frac{\text { Alloy }}{\mathrm{Mg}-8 \mathrm{~A} 1-0.05 \mathrm{Be}}$
$\mathrm{Mg}-5 \mathrm{~A} 1-2 \mathrm{~Pb}-0.05 \mathrm{Be}$
$\mathrm{Mg}-3 \mathrm{Al}-1 \mathrm{Zn}-0.2 \mathrm{Mn} \quad(\mathrm{AZZ} 3 \mathrm{~B})$
$\mathrm{Mg}-5 \mathrm{~A} 1-2 \mathrm{Sn}$
$\mathrm{Mg}-5 \mathrm{~A} 1-2 \mathrm{Sn}-0.25 \mathrm{Cu}$
$\mathrm{Mg}-2 \mathrm{Sn}-0.2 \mathrm{Ca}$

Corrosion Rate at $80^{\circ} \mathrm{C}$, $\mathrm{mg} /\left(\mathrm{dm}^{2}-\right.$ day $)$

\begin{tabular}{cc} 
Before & After \\
\hline 9.5 & 12 \\
12 & 14 \\
14 & 14 \\
14 & 17 \\
14 & 20 \\
20 & 20
\end{tabular}

Small concentrations of iron in magnesium alloys severely accelerate corrosion in high conductivity (sea) water. A concentration of $<0.02 \mathrm{wt} \% \mathrm{Fe}$ is recommended for such service. ${ }^{5,6}$ Four special $\mathrm{Mg}-\mathrm{Fe}$ alloys were tested in $80^{\circ} \mathrm{C}$ refreshed, deionized water for eight days to assess the deleterious effects of iron. The average corrosion rates for these alloys (Table II) show that corrosion of magnesium in low conductivity water is essentially unaffected by iron contents up to $0.1 \mathrm{wt} \%$ in contrast to the results for high conductivity seawater. The range of corrosion rates in Table II is about equal to experimental error.

\section{TABLE II}

Effect of Iron on Corrosion of Magnesium in Low Conductivity Water

Alloying Element, wt \%

\begin{tabular}{|c|c|c|c|c|c|}
\hline $\mathrm{Fe}$ & $\mathrm{Al}$ & $\mathrm{Mn}$ & $\mathrm{Ni}$ & Others & $\begin{array}{c}\text { Corrosion Rate, } \\
\mathrm{mg} /\left(\mathrm{dm}^{2}-\mathrm{day}\right)\end{array}$ \\
\hline 0.002 & 0.003 & 0.002 & 0.001 & - & 24 \\
\hline 0.037 & 0.003 & 0.002 & 0.001 & - & 25 \\
\hline 0.050 & 0.005 & 0.072 & 0.002 & - & 22 \\
\hline 0.096 & $<0.03$ & $<0.01$ & 0.002 & $0.02 \mathrm{~Pb}$ & 24 \\
\hline
\end{tabular}

The second series of 15 new alloys were homogenized in billet form, then extruded at high reduction to further increase uniformity and to break up billet grain boundaries. Corrosion results for nine of the alloys are compared to $99.96 \% \mathrm{Mg}$ in Figure 6 . 


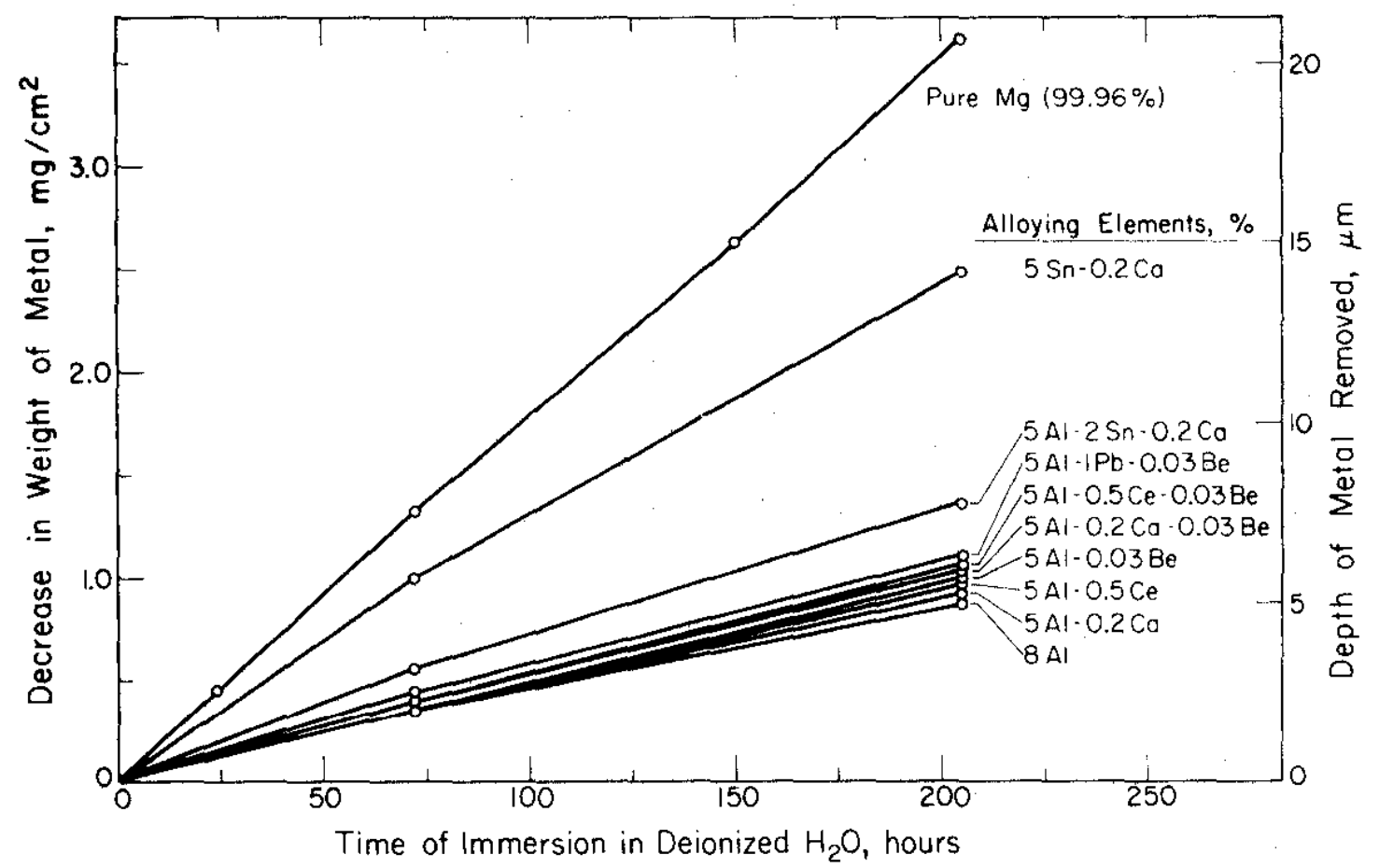

FIG. 6 Corrosion Evaluation of Hornogenized Alloys 
The corrosion rates for the most resistant alloys in both groups of specimens are shown in Table III. The two evaluations are comparable, based on the corrosion rates of $99.96 \% \mathrm{Mg}$ used as internal standards. The standards varied $\pm 5 \%$ from the average corrosion rate at the $67 \%$ confidence level.

\section{TABLE III}

Corrosion Rates of Selected Magnesium Alloys in Refreshed, $80^{\circ} \mathrm{C}$ Deionized Water ${ }^{a}$

\begin{tabular}{|c|c|c|c|}
\hline Alloying Element, wt \% & $\begin{array}{l}\text { Weight Loss, } \\
\mathrm{mg} /\left(\mathrm{dm}^{2}-\text { day }\right)\end{array}$ & $\begin{array}{l}\text { Average } \\
\mu \mathrm{m} / \text { day } \\
\end{array}$ & $\begin{array}{l}\text { Penetration, } \\
\text { (mils/day) }\end{array}$ \\
\hline $8 \mathrm{Al}-0.05 \mathrm{Be}$ & 9.5 & 0.50 & $(0.02)$ \\
\hline $8 \mathrm{Al}$ & 10 & 0.55 & $(0.02)$ \\
\hline $5 \mathrm{Al}-0.2 \mathrm{Ca}$ & 11 & 0.61 & $(0.02)$ \\
\hline $5 \mathrm{~A} 1-2 \mathrm{~Pb}-0.05 \mathrm{Be}$ & 12 & 0.62 & $(0.02)$ \\
\hline $5 \mathrm{Al}-0.05 \mathrm{Be}$ & 12 & 0.63 & $3(0.02)$ \\
\hline $5 \mathrm{~A} 1-0.5 \mathrm{Ce}$ & 12 & 0.65 & $(0.03)$ \\
\hline $5 \mathrm{Al}-0.5 \mathrm{Ce}-0.3 \mathrm{Be}$ & 12 & 0.65 & $(0.03)$ \\
\hline $5 \mathrm{~A} 1-0.2 \mathrm{Ca}-0.03 \mathrm{Be}$ & 12 & 0.66 & $(0.03)$ \\
\hline $5 \mathrm{~A} 1-1 \mathrm{~Pb}-0.03 \mathrm{Be}$ & 13 & 0.62 & $(0.02)$ \\
\hline $10 \mathrm{~A} 1-0.08 \mathrm{Be}$ & 13 & 0.68 & $3(0.03)$ \\
\hline $5 A I-2 S n$ & 14 & 0.74 & $4(0.03)$ \\
\hline $5 \mathrm{~A} 1-2 \mathrm{Sn}-0.25 \mathrm{Cu}$ & 14 & 0.74 & $+(0.03)$ \\
\hline $3 \mathrm{~A} 1-0.2 \mathrm{Ca}$ & 14 & 0.80 & $(0.03)$ \\
\hline $1 \mathrm{Si}$ & 14 & 0.80 & $(0.03)$ \\
\hline $99.96 \% \mathrm{kgg}$ & 43 & 2.5 & $(0.10)$ \\
\hline
\end{tabular}

a. Inlet water $\mathrm{pH} \sim 7$; overflow water $\mathrm{pH} 8-9$

Most of these alloys were also tested in a flowing water loop with controlled flow, temperature, and pit, as described on page 18.

\section{Cercomics}

Several ceramic materials were selected to give the same neutron spectrum as $\mathrm{Mg}-10 \mathrm{Al}$. These materials were $\mathrm{MgO}$ at $30 \%$ theoretical density, $\mathrm{MgAl}_{2} \mathrm{O}_{4}$ at $70 \% \mathrm{TD}$, and $\mathrm{Bi}_{2} \mathrm{O}_{3}$ at $100 \% \mathrm{TD}$. Although the densities indicated were required for the reactor application, the materials were generally tested at $90-100 \% \mathrm{TD}$, because desired densities were not commercially available. $\mathrm{MgAl}_{\mathbf{2}} \mathrm{O}_{4}$ was found to be the best ceramic, based on its low cost and low attack rate. 
The ceramics were tested under the same conditions as used for the metal alloys: $80^{\circ} \mathrm{C}$ refreshed, overflowing, deionized water. Structural damage or rapid deterioration of the ceramic were the criteria used to eliminate candidates. The density and purity of all ceramics evaluated are listed in Appendix B. $\mathrm{MgAl}_{2} \mathrm{O}_{4}$ was virtually unattacked (Figure 7). Although $\mathrm{Bi}_{2} \mathrm{O}_{3}$ was expected to be about equivalent to $\mathrm{MgAl}_{2} \mathrm{O}_{4}$, grain spallation occurred; after 240 hours the surface voids originally present had increased in size 2 to 5 times. $\mathrm{MgO}$ at $98 \%$ theoretical density was similar to $\mathrm{Bi}_{2} \mathrm{O}_{3}$, in that weight loss due to spallation of small crystals accompanied exposure. The MgO at $100 \%$ theoretical density appeared similar to the $98 \%$ theoretical density material until 170 hours exposure, when spalling became severe. The spalling and cracking in MgO specimens was probably due to stresses arising from hydration to $\mathrm{Mg}(\mathrm{OH})_{2}$, which has about half the density of $\mathrm{MgO}$.



FIG. 7 Effects of Exposure of Ceramics to $80^{\circ} \mathrm{C}$ Water

Mgo either lost or gained weight depending on its initial density (Figure 7). The higher density specimens tended to spall and lose weight. Additionally, the purest Mgo (99.96\%) hydrated, spalled, and lost weight faster than less pure specimens ( 98.2 to $99.6 \%$ ) of about the same density because the impurities decreased 
the rate of hydration. Low density Mgo also hydrated rapidiy, and because of the greater porosity, hydration occurred throughout the structura, not only on the surface as for the high denstity material. whe low density specimens thus swelled and cracked wth ondy a small amount of spalling. Bxamples of the effects of water on the ceramics are shown in Figure 8. No effects of surface attack were observed on the $\mathrm{MgAl}_{2} \mathrm{O}_{4}$.

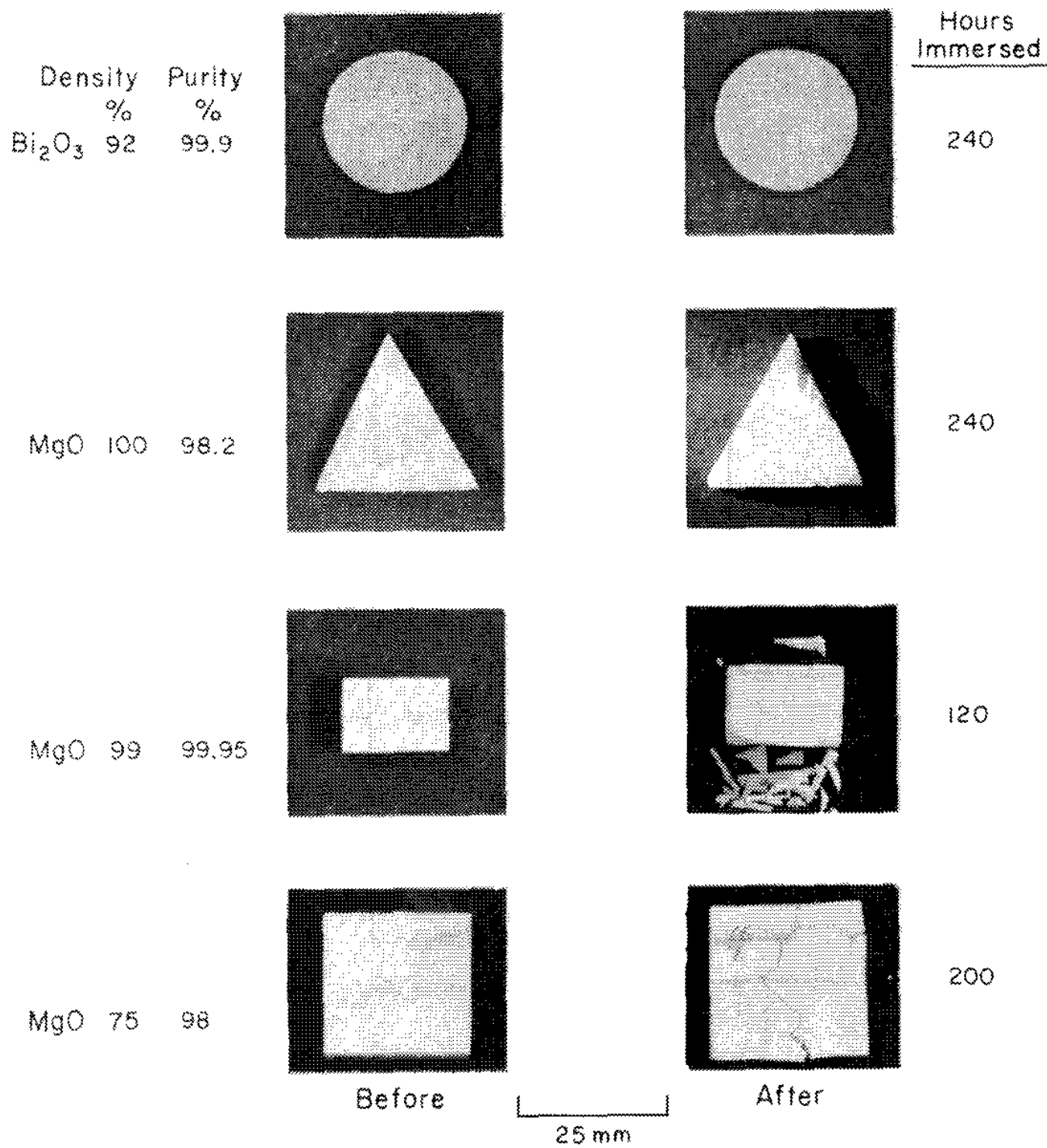

FG. 8 Spalling and Cracking of Ceramics in $80^{\circ} \mathrm{C}$ Water 


\section{CORROSION IN FLOWING WATER}

\section{Experimental Technique}

To mock up the in-service conditions of a nuclear reactor, a special corrosion loop was fabricated (Figure 9). This loop allowed control of test conditions to simulate expected attack by water in the temperature range of 80 to $110^{\circ} \mathrm{C}$ at a pH controlled to about 5. The $\mathrm{pH}$ of the deionized water was adjusted by nitric acid addition that had to be balanced against deionizer removal and neutralization of corrosion products. Temperature $\left( \pm 2^{\circ} \mathrm{C}\right)$, $\mathrm{pH}$, and water resistivity were controlled and continuously recorded.

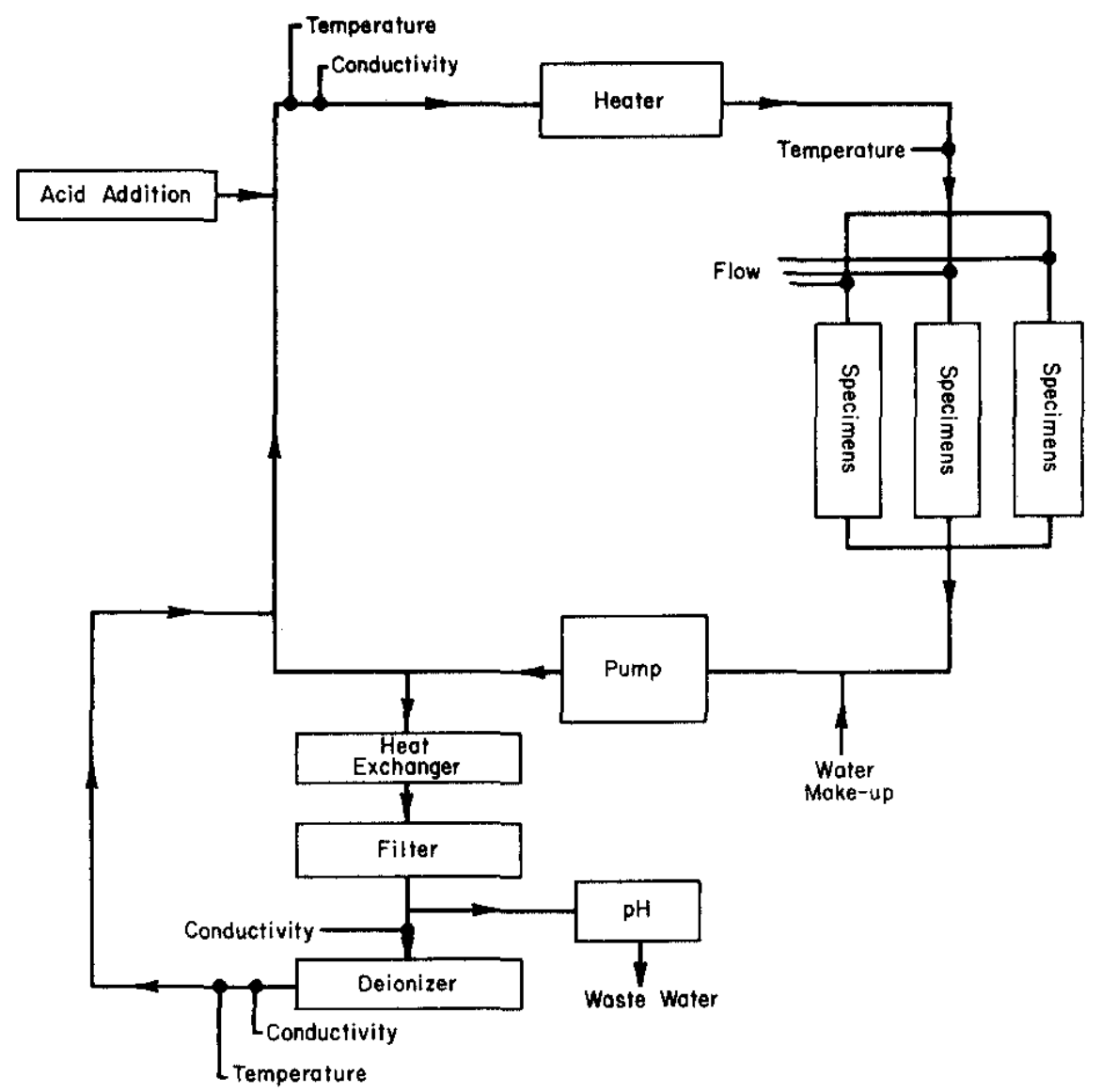

FIG. 9 Corrosion Loop Schematic 
Test specimens were supported in a "Teflon" holdex to prem vent galvanic acceleration of corrosion. Each holder (Figure 10) included a apecimen of $99.96 \% \mathrm{Mg}$ to be used a a control for com partson. A stanless sted flow guide, upstream of the samples, assured a uniform flow over each sample at $5 \mathrm{tt} / \mathrm{sec}$.

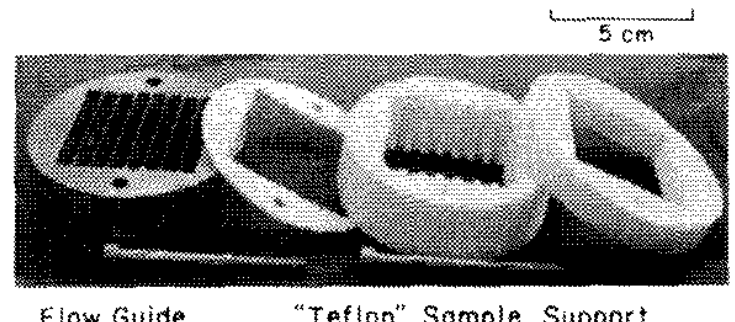

FIG. 10 Loop Sample Holder

Duplicates of 15 alloys were evaluated in two tests; the conditions are shown in Table IV. Resistivity of the water in the 7 way test was lowe than that for the 4 mday test because the samples used in this evaluation (21 vs 18 ) produced moxe

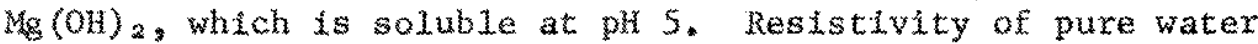
acidified to ple 5 with $\mathrm{HNO}_{3}$ is $23 \times 10^{3}$ ohm- $\mathrm{cm}$.

TABLE IV

\section{Typical Loop Corrosion Conditions}

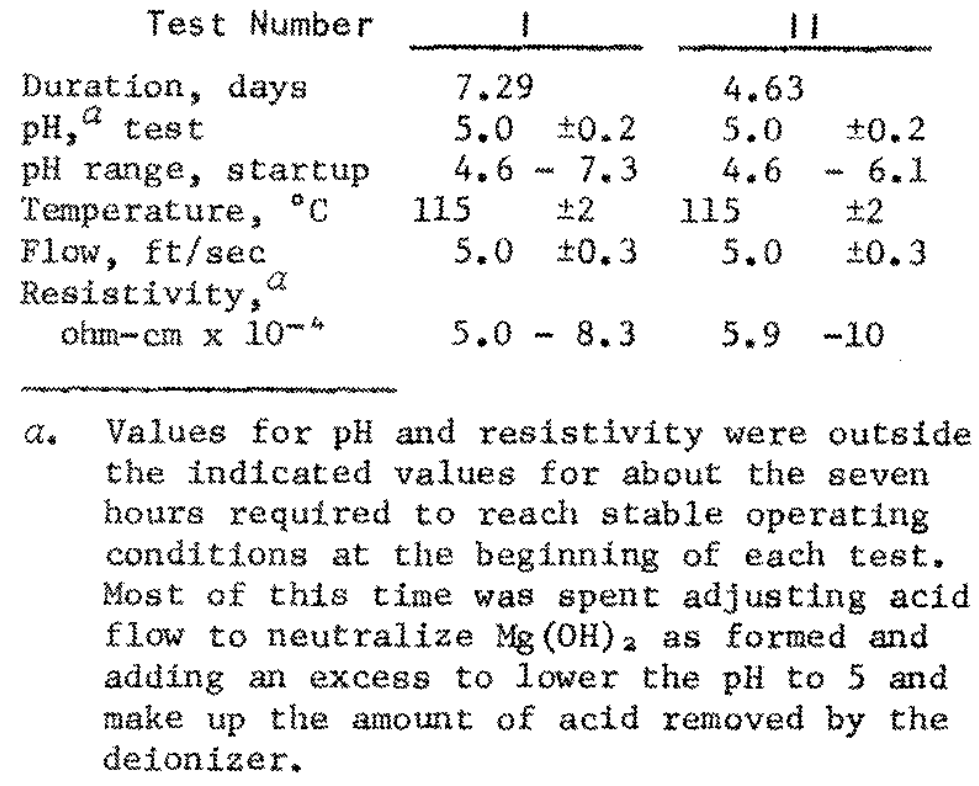

* Dupont tradenark for fluorocarbon resin 
Loop corrosion evaluation of 15 magnesium alloys chosen after the initial laboratory evaluation showed that $5 \mathrm{Al}-2 \mathrm{Sn}, 1 \mathrm{Si}, 5 \mathrm{Al}-$ $0.5 \mathrm{Ce}$, and $3 \mathrm{~A} 1-0.2 \mathrm{Ca}$ were the best suited alloys for displacer use based on corrosion and composition requirements. These alloys are all more corrosion resistant than the commercial alloy AZ31B (Mg-3A1-1Zn-0.2Mn) under the conditions of evaluation. However, in $\mathrm{pH} 5$ water, magnesium alloys corroded rapidly, and all alloys must be clad to prevent attack.

Results for the more resistant alloys at $115^{\circ} \mathrm{C}$ are shown in Table $\mathrm{V}$ and compared to $99.96 \% \mathrm{Mg}$. The most corrosionresistant alloys reacted about $1 / 4$ as rapidly as the pure magnesium standards, which lost 40-60\% of their weight during the test period. The corrosion rate of the six standards varied $\pm 3.0 \%$ from the average at the $95 \%$ confidence level, thus indicating that control of the corrosion conditions was quite good. Variation in corrosion rates for duplicate samples was $<5 \%$.

\section{TABLE V}

Magnesium Alloy Corrosion Rates at $115^{\circ} \mathrm{C}$

\begin{tabular}{|c|c|c|}
\hline $\begin{array}{c}\text { Concentration of } \\
\text { Alloy Elements, } \\
\text { wt \% }\end{array}$ & $\begin{array}{l}\text { Weight Loss, } \\
\mathrm{mg} /\left(\mathrm{dm}^{2}-\mathrm{day}\right)\end{array}$ & $\begin{array}{l}\text { Average Penetration, } \\
\mu \mathrm{m} / \text { day (mi Is/day) }\end{array}$ \\
\hline $5 \mathrm{~A} 1-2 \mathrm{Sn}$ & 570 & $30(1.2)$ \\
\hline $5 \mathrm{Al}-2 \mathrm{Sn}-0.25 \mathrm{Cu}$ & 590 & $31(1.2)$ \\
\hline $1 \mathrm{Si}$ & 700 & $40(1.6)$ \\
\hline $3 \mathrm{Al}-0.2 \mathrm{Ca}$ & 720 & $41(1.6)$ \\
\hline $5 \mathrm{Al}-0.5 \mathrm{Ce}$ & 740 & $41(1.6)$ \\
\hline $5 \mathrm{Al}-1 \mathrm{~Pb}-0.03 \mathrm{Be}$ & 800 & $41(1.6)$ \\
\hline $5 \mathrm{~A} 1-0.5 \mathrm{Ce}-0.03 \mathrm{Be}$ & 810 & $44(1.7)$ \\
\hline $3 \mathrm{~A} 1-1 \mathrm{Zn}-0.2 \mathrm{Mn}(\mathrm{AZ} 31 \mathrm{~B})^{a}$ & 810 & $44(1.7)$ \\
\hline $5 \mathrm{AI}-0.03 \mathrm{Be}$ & 840 & $44(1.7)$ \\
\hline $5 \mathrm{Al}-0.2 \mathrm{Ca}$ & 870 & $48(1.9)$ \\
\hline $8 \mathrm{AI}{ }^{a}$ & 920 & $51(2.0)$ \\
\hline $99.96 \mathrm{Mg}$ & 1880 & $108(4.3)$ \\
\hline
\end{tabular}

a. Unsatisfactory for moderator displacers because of nuclear properties. 
The alloys can be classified into three different groups based or corrosion resistance (Table $V$ ). The two most resistant alloys had penetration rates of about $30 \mathrm{um} / \mathrm{day}(1.2 \mathrm{mils} / \mathrm{day})$, sever intermedate alloys corroded at about $44 \mathrm{um} / \mathrm{day}$ (1.7 mils/ day), and the remaining alloys at rates about $50 \mathrm{hm} / \mathrm{day}(2.0$ mis/day) or faster. For moderator displacers, the simplest alloys and the ones whth the least anount of aluminum are the logical cholces because of easy conpostiton control and because of the nuclear properties of aluminum.

Two of the magnestum alloys ( $8 \mathrm{Al}$ and $5 \mathrm{Al}-0.5 \mathrm{Ce}$ ) were evalum ated in both the extruded and annealed condtions to assess the unportance of internal stresses in corrosion. As expected, the extruded spectmens corroded more rapidiy than the annealed structures; however, the differences in the rates were small, $4 \%$ for the $8 \mathrm{~A}$ and $9 \%$ for the 5Al-0.5Ce.

Several types of corrosion were observed on the various specim mencs (Figure 11). Exfoltation, the formation and sloughing off of thing layers of corrosion product, occurred on $99.96 \% \mathrm{Mg}$. This type of attack is generally indicative of rapidly corroding matartal. Pitting that was wde and shallow was observed on only one alloy the commercial corrosion-reststant Az31B (3A1-12n-0.2Mn). A unform attack with a resulting grey suxface occurred on $5 A 1 m 2 \operatorname{sn} ;$ addition of 0.25 wt \% copper to this alloy caused the corrosion appearance to change to a less unfforn attack, but had no effect on the corrosion rate. The rematndex of the alloys corroded wh a slight surface rotghening, which was meither a miform attack nor a pitting form of corrosion.

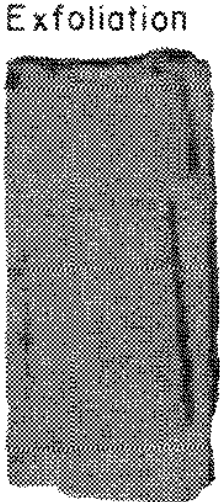

$99.96 \mathrm{Mg}$

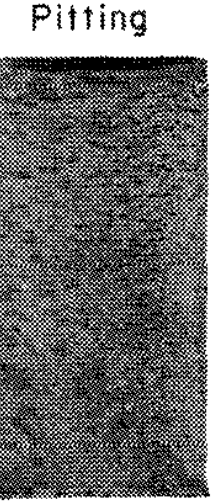

$3 \mathrm{~A}|\sim| \mathrm{Zn}+$ $0.2 \mathrm{Mn}$
Uniform

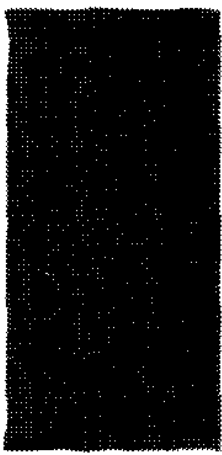

$5 A \mid-2 S n$
Nonuniform

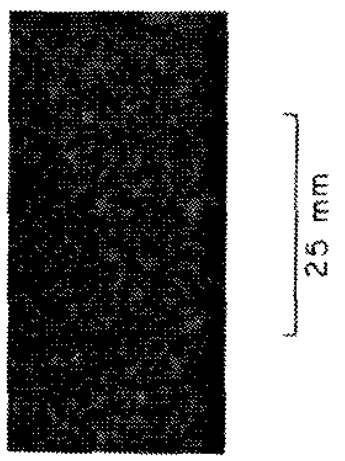

5 Al -2 Si$0.25 \mathrm{Cu}$

FIG. 11 Types of Corrosion Observed on Magnesium Alloys 
Several of the more resistant alloys were evaluated at 80 , 100 , and $115^{\circ} \mathrm{C}$ to obtain data on the temperature dependence of corrosion. The 5Al-2Sn alloy continued to corrode least (Table VI).

\section{TABLE VI}

Temperature Effect on Magnesium Alloy Corrosion in Flowing Water

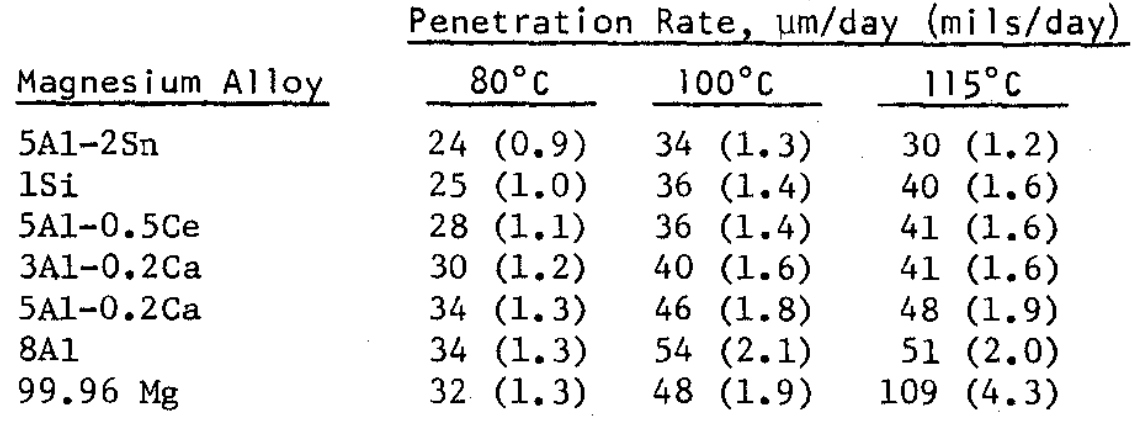

a. Flow rate was $5 \mathrm{ft} / \mathrm{sec}$ and $\mathrm{pH} 5.0 \pm 0.2$

The corrosion rates of the alloys at $80^{\circ} \mathrm{C}$ are measured at $\mathrm{pH} 5$, rather than $8-9$, and a flow of $5 \mathrm{ft} / \mathrm{sec}$, rather than ${ }^{0}$. These conditions resulted in much more rapid penetration than observed previously in "static" tests (compare Table III with Table VI).

The relative effects of increasing temperature on the corrosion penetration rate of several alloys and $99.96 \% \mathrm{Mg}$ are compared in Figure 12. The rate for magnesium increases much more rapidly with temperature, in the range evaluated, than that for the alloys; thus the alloying additions become increasingly important with increasing temperature. A difference in corrosion mechanism between the alloys and $99.96 \% \mathrm{Mg}$ is shown by an Arrhenius plot of the data (Figure 12) and can be explained on the basis of the type of attack. Exfoliation would tend to produce a larger surface area for attack by hot water, and therefore to give a corrosion rate increase not seen in typical surface attack of the other alloys. 


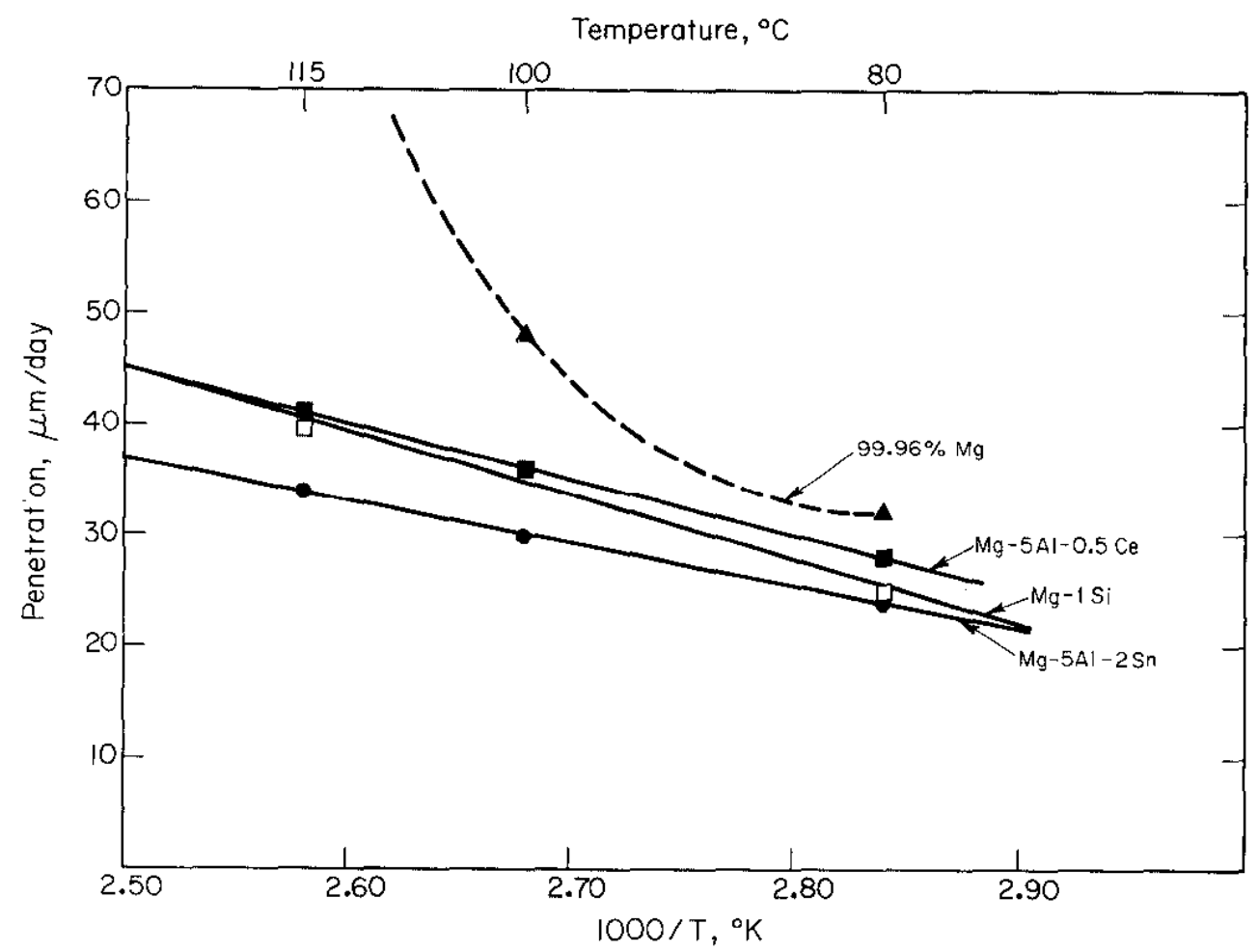

FIG. 12 Effect of Some Alloying Elements on Magnesium Corrosion

The data in Table VI and Figure 12 are conservative for corrosion of magnesium alloys. The rates are high and pseudozero order (i.e., constant rate, no concentration effect) over the periods of time studied because of the solubility of the corrosion products at $\mathrm{pH} 5$ and the removal of the ions by ion exchange purification. In practice, however, if the cladding of the alloy were penetrated by a "pinhole", the flow of water would be restricted, and the $\mathrm{pH}$ would increase inside the defect and lower the corrosion rate. In this situation, the corrosion reaction would be expected to approach a first order, rather than zero order reaction, and the corrosion rates would be much lower than observed in this study.

\section{EVALUATION OF CLADDING PENETRATION}

To assure that no unacceptable effects occur in the event of penetration of the aluminum cladding and exposure of the magnesium alloys to the moderator, three questions must be answered: (I) What is the composition of the film formed over the magnesium during corrosion? (2) Is corrosion galvanically accelerated because of the small anodic magnesium area adjacent to the large 
area of cladding? (3) Is the aluminum cladding adjacent to penetration attacked by the basic solution, which is formed by $\mathrm{Mg}(\mathrm{OH})_{2}$ dissolution when the hole is small enough to restrict moderator flow in the penetrated area?

$\mathrm{Mg}(\mathrm{OH})_{2}$, the hydroxide formed on pure magnesium during corrosion in water, is soluble $(43 \mu \mathrm{g} / \mathrm{ml})$ in water at $100^{\circ} \mathrm{C}$. Thus, magnesium depletion should occur during corrosion, and the hydroxide formed on alloys would be anticipated to be low in magnesium and high in alloying elements. To evaluate this possible effect, AZ31B (Mg-3A1-1Zn-0.2Mn) was exposed to refreshed $100^{\circ} \mathrm{C}$ water for 25 days. Comparisons of the analyses of the elements in the alloy and hydroxide film are shown in Table VII.

\section{TABLE VI I}

\section{Alloying Elements in AZ3lB and Corrosion Film}

Element-to-Magnesium Weight Ratio

\begin{tabular}{|c|c|c|c|c|}
\hline & $\mathrm{Al}-\mathrm{Mg}$ & $\mathrm{Zn}-\mathrm{Mg}$ & $\mathrm{Mn}-\mathrm{Mg}$ & $\mathrm{Fe}-\mathrm{Mg}$ \\
\hline & & 6 & 3 & 0.0006 \\
\hline & 0.183 & 0.0153 & 0.0067 & 0.0019 \\
\hline
\end{tabular}

A significant enrichment in the hydroxide film, up to a factor of 6 for aluminum, is observed for each of the alloy elements. This enrichment is caused by the solubility of the $\mathrm{Mg}(\mathrm{OH})_{2}$, which decreased the magnesium content of the hydroxide film. The metal contains $96 \% \mathrm{Mg}$; therefore, the hydroxide film should contain $39 \% \mathrm{Mg}$ if no losses occurred. The film actually contained $32 \%$ $\mathrm{Mg}$.

Galvanic corrosion occurs when two dissimilar metals are electrically connected and immersed in an aqueous solution. The more anodic metal begins to oxidize, and the cathodic metal generally discharges $\mathrm{H}^{+}$to release $\mathrm{H}_{2}$. As the size of the anode is decreased or the cathode increased, corrosion can be accelerated by the relative increase in current density at the anodic area unless there is some interference to charge transfer. To evaluate possible corrosion acceleration due to galvanic effects, flat specimens of $A Z 31 B(M g-3 A 1-1 Z n-0.21 \mathrm{n})$ were clad on both sides with $1100 \mathrm{Al}$. Specimens with different cathodic/anodic ratios were fabricated and exposed to refreshed, high resistivity $\left(5 \times 10^{6} \mathrm{ohm}-\mathrm{cm}\right)$ water at $100^{\circ} \mathrm{C}$. The corrosion rates or depths of penetration after various exposures are shown in Table VIII. 


\section{TABLE VIII}

\section{Effect of Increasing Cathodic Area on Magnesium Corrosion}

\begin{tabular}{ccccc}
$\begin{array}{c}\text { Cathode/Anode } \\
\text { Ratio }\end{array}$ & & \multicolumn{2}{c}{ Average Penetration, $\mu m$ (mi ls) } \\
\cline { 1 - 1 } 0 (no A1) & & $\frac{\text { After } 5 \text { days }}{56(2.2)^{a}}$ & $\frac{\text { After } 9 \text { days }}{71(2.8)^{a}}$ & $\frac{68(2.7)^{a}}{\text { After } 12 \text { days }}$ \\
8 & $30(1.2)$ & $50(2.0)$ & $87(3.4)^{a}$ \\
23 & $30(1.2)$ & $50(2.0)$ & $85(3.4)^{a}$ \\
78 & $31(1.2)$ & $48(1.9)$ & $74(2.9)^{a}$
\end{tabular}

a. Corrosion product covers magnesium alloy

Galvanically accelerated corrosion was not observed although the absolute corrosion rate was high. Corrosion product buildup accompanied exposure although water circulated freely over the surface. Additionally, the corrosion current and thus the corrosion rates may have been minimized by the low conductivity water and nay have been further reduced by the corrosior product buildup.

Poor circulation of water, a condition that would be expected in the event of a small hole in the cladding, did not affect corrosion of magnesium, although the aluminum cladding was attacked because of the $\mathrm{pH}$ change that accompanied corrosion. AZ31B specimens clad with $1100 \mathrm{Al}$ we re exposed to water at $100^{\circ} \mathrm{C}$ with "pinholes" 1/16 in. in diameter drilled through one side of the cladding, through the magnesium, and into the other side of the aluminum cladding. The $\mathrm{pH}$ inside the hole would be expected to increase toward the equilibrium value of 10.2 at $100^{\circ} \mathrm{C}$. A high $\mathrm{pH}$ would be expected to decrease the corrosion rate of magnesium and cause the attack of aluminum. Figure 13 shows the result after 40 days exposure at $100^{\circ} \mathrm{C}$. No corrosion product was observed in the hole. This is attributed to the dissolution of the surface film and apparently resulted in a high $\mathrm{pH}$ in the "pinhole."

The corrosion rate of the magnesium alloy in the hole was only slightly greater than the rate on bare specimens and again indicated that a high cathode/anode ratio does not greatly affect corrosion rates of magnesium in low conductivity water. The magnesium alloy corroded at $\sim j \mu \mathrm{m} /$ day $(0.04 \mathrm{mil} /$ day $)$ in the clad pinholed specimens and $0.8 \mu \mathrm{m} /$ day $(0.03 \mathrm{mil} /$ day $)$ in unclad specimens. The aluminum at the Mg-Al interface was attacked about twice as rapidly as the adjacent magnesium. This rapid corrosion of aluminum is attributed to the high local $\mathrm{pH}$. 


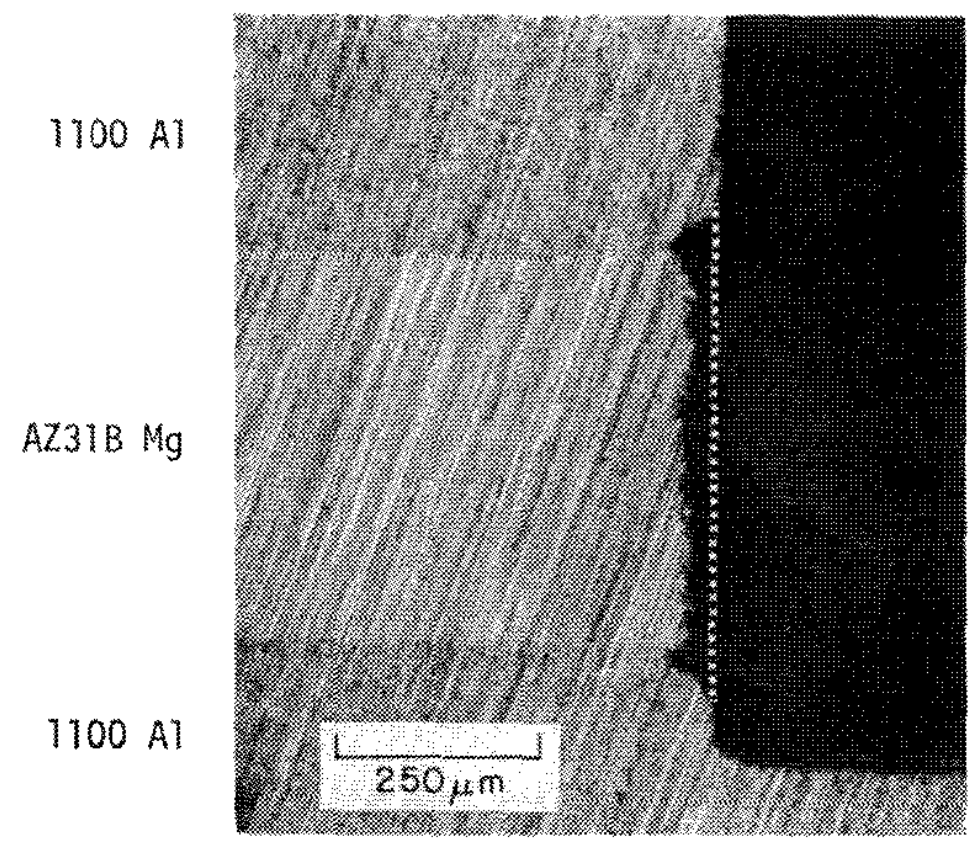

a. Note corrosion of $\mathrm{Mg}$ and attack of $\mathrm{Al}$ cladding at $\mathrm{Mg}-\mathrm{Al}$ interfaces in hole.

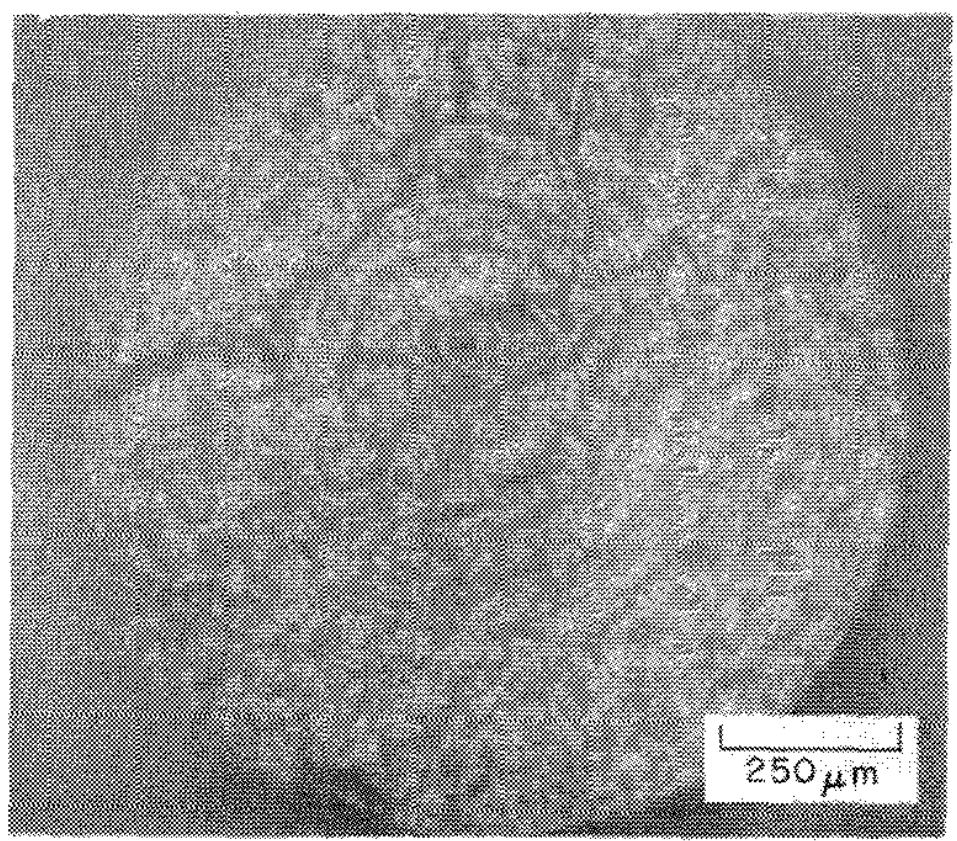

b. Looking down into the hole, the Al cladding is attacked as shown by the partial obliteration of tool marks (concentric circles)

FIG. 13 Attack of Aluminum Clad Magnesium in "pinhole" Through Cladding 


\section{APPENDIX A}

Magnesium Alloys for Corrosion Evaluation

wt \% Alloying Element

\begin{tabular}{|c|c|c|c|c|c|c|c|c|c|c|c|}
\hline Al & $\mathrm{Be}$ & $\mathrm{Ca}$ & $\mathrm{Ce}$ & $\mathrm{Cu}$ & $\mathrm{Fe}$ & $M n$ & $\mathrm{~Pb}$ & $\mathrm{Si}$ & $S_{n}$ & $\mathrm{Zn}$ & $\mathrm{Zr}$ \\
\hline $\begin{array}{r}10^{a} \\
8^{a}\end{array}$ & 0.1 & & & & & & & & & & \\
\hline $8^{a}$ & 0.05 & & & & & & & & & & \\
\hline 5 & 0.03 & & & & & & & & & & \\
\hline 5 & & 0.2 & & & & & & & & & \\
\hline 5 & & & 0.5 & & & & & & & & \\
\hline 5 & $\begin{array}{l}0.03 \\
0.03\end{array}$ & 0.2 & & & & & & & & & \\
\hline $\begin{array}{l}5 \\
5\end{array}$ & $\begin{array}{l}0.03 \\
0.03\end{array}$ & & 0.5 & & & & 1.0 & & & & \\
\hline $\begin{array}{l}5 \\
5\end{array}$ & 0.03 & & & & & & 1.0 & & 2.0 & & \\
\hline $\begin{array}{l}5 \\
5\end{array}$ & & 0.2 & & & & & & & 20 & & \\
\hline $\begin{array}{l}5 \\
5\end{array}$ & & 0.2 & 0.2 & & & & & & 2.0 & & \\
\hline$\frac{5}{5} b$ & & & & 0.2 & & & & & 2.0 & & \\
\hline $\begin{array}{l}5^{D} \\
5\end{array}$ & 0.03 & 0.1 & 0.1 & & & & & & $\begin{array}{l}2.0 \\
2.0\end{array}$ & & \\
\hline $\begin{array}{l}5 \\
5\end{array}$ & 0.05 & & & & & & 2.0 & & & & \\
\hline 5 & & & & & & & 10.0 & & & & \\
\hline 5 & 0.05 & & & & & & 10.0 & & & & \\
\hline 3 & & 0.2 & & & & & & & & & \\
\hline 3 & 0.03 & & & & & & & & & & \\
\hline 0.7 & & 0.2 & & & & & & & & & \\
\hline 0.2 & & 0.5 & & & & & & & & & \\
\hline$<0.03$ & & & & & 0.1 & $<0.01$ & 0.02 & & & & \\
\hline 0.005 & & & & & 0.05 & 0.07 & & & & & \\
\hline 0.003 & & & & & 0.04 & 0.002 & & & & & \\
\hline 0.003 & & & & & 0.002 & 0.002 & & & & & \\
\hline 0.002 & & & & & & & & & & & \\
\hline & 0.05 & $\begin{array}{l}0.2 \\
0.2\end{array}$ & & & & & & & & & \\
\hline & & & 0.5 & & & & 10 & & & & 0.5 \\
\hline & 0.03 & & & & & & & 1.0 & 5.0 & & \\
\hline & & 0.2 & & & & & & & 5.0 & & \\
\hline & & & 0.5 & & & & & & 5.0 & & \\
\hline & 0.03 & 0.2 & & & & & & & 5.0 & & \\
\hline & & 0.2 & & & & & & & 3.0 & & 0.01 \\
\hline & & & & & & & & & & & 0.5 \\
\hline & & 0.2 & & & & & & & & & 0.5 \\
\hline & 0.05 & & & & & & & & & & 0.5 \\
\hline & & & 0.5 & & & & & & & & 0.5 \\
\hline & & & & & & & & & & 6 & 0.5 \\
\hline $3^{c}$ & & & & & & 0.2 & & & & 1 & \\
\hline $6^{c}$ & & & & & & 0.2 & & & & 3 & \\
\hline $9^{c}$ & & & & & & 0.2 & & & & 0.7 & \\
\hline
\end{tabular}

a. Neutron properties unsatisfactory; used to determine effect of AI on corrosion.

b. Corrosion-resistant alloy, recommended by Argonne National Laboratory.

c. Commercial alloys AZ31B, AZ61, and AZ91, respectively. Physics properties unsatisfactory; used for comparison to experimental alloys. 


\section{APPENDIX B}

\section{Ceramics for Corrosion Evaluation}

\begin{tabular}{lcc} 
Ceramic & Theoretical Density, $\%$ & Purity, wt \% \\
\cline { 2 - 3 } $\mathrm{Bi}_{2} \mathrm{O}_{3}$ & 92 & 99.9 \\
$\mathrm{MgAl}_{2} \mathrm{O}_{4}$ & 95 & 99 \\
$\mathrm{MgO}$ & 75 & 98 \\
$\mathrm{MgO}$ & 98 & 99.6 \\
$\mathrm{MgO}$ & 99 & 99.96 \\
$\mathrm{MgO}$ & 100 & 98.2
\end{tabular}

\section{ACKNOWLEDGMENTS}

The author wishes to thank E. F. Sturcken for his assistance in procuring magnesium alloys from Dow Chemical Company and W. E. Ruther for supplying a number of alloy samples that had been evaluated at Argonne National Laboratory. M. E. Epting made most of the experimental measurements, and J. W. Lane was responsible for loop operation.

\section{REFERENCES}

1. C. S. Roberts. Magnesium and Its AZloys. John Wiley and Sons, New York, N. Y. (1960).

2. T. J. Heal. "Magnesium and Its Alloys." Nucl. Eng. 3, 52 (1958).

3. S. Greenburg and W. E. Ruther. Aqueous Corrosion of Magnesium AlZoys. USAEC Report ANL-6070, Argonne National Laboratory, Argonne, IIl. (1960).

4. Magnesium. ASM Lectures, American Society for Metals, Cleveland, Ohio (1946).

5. J. D. Hanawalt, C. E. Nelson, and J. A. Peloubet. "Corrosion Studies of Magnesium and Its Alloys." Trans. AIME 147, 273 (1942).

6. C. J. Bushrod. "Note on the Quantitative Implications of Hanawalts' Theory of Corrosion of Magnesium-Base Alloys." J. Inst. Metals 73, 567 (1947). 